\title{
Influence of a specialized training program on the changes in the level of balance abilities in 8-10 year old alpine skiers
}

\author{
Ivan Čillík* and Zuzana Rázusová \\ Faculty of Arts, Matej Bel University, Banská Bystrica, Slovak Republic
}

Copyright: (C) 2014 I. Čillík and Z. Rázusová. This is an open access article licensed under the Creative Commons Attribution License (http://creativecommons.org/licenses/by/4.0/).

Background: Alpine skiing is a sport with a very complex structure and a high variability of movements. The stage of preliminary sport preparation in alpine skiing is important in a relation to the need of creating physical demands which enable an optimal and continuous growth of the performance. Inline skating is a very good substitution with a similar loading of lower limbs and muscle involvement as in skiing because inline skates offer a sense of sliding; stance and edge change and the technique for making curves are very similar. Objective: The main purpose of this paper was to assess the influence of a 9 week specialized training program on the changes in the level of balance abilities development of 8-10 year old children in alpine skiing. This specialized training program consisted of exercises on inline skates and from balance exercises on non-specific equipment. Methods: This research was organized by using a single-factor parallel experiment with two groups. Specialized motion program was 9 weeks long and it was used in the experimental group during the preparatory period in the stage of preliminary sport preparation. The experimental group completed a total of 90 minutes of specialized training per week, of which 60 minutes were special exercises on inline skates and 30 minutes were exercises for development of balance skills on non-specific tools. The control group underwent generally focused training. To determinate the level of balance we used tests of both static and dynamic balance. Results: Based on the tests results we found statistically significant improvement of the performance in all of the tests for balance abilities in the experimental group due to the specialized training program. The control group showed no significant differences during generally focused training process on the development of physical abilities. Conclusions: A 9 week training program consisting of 3 training sessions per week was long enough to have a positive influence on the development of balance abilities of children of school age in alpine skiing. We included specific ski-motions into the nonspecific movements using methods for the development of balance abilities in the duration of 30 minutes at the beginning of each training session.

Keywords: alpine skiing, the stage of preliminary sport preparation, preparation period, static balance, dynamic balance

\section{Introduction}

Sport training for children in alpine skiing and the structure of training process is oriented with the respect to requirements of the structure of performance. Today, the stage of preliminary sport preparation in alpine skiing is often discussed with the need to create physical demands which enable an optimal and continuous growth in performance. The trend which is currently occurring in youth categories in alpine skiing is the rapid increase in performance due to excessive loading of a child's body. By increasing the trainability through larger volumes of training sessions, children

\footnotetext{
* Address for correspondence: Ivan Čillík, Department of Physical Education and Sports, Faculty of Arts, Matej Bel University, Tajovského 40, 97401 Banská Bystrica, Slovak Republic. E-mail: ivan.cillik@umb.sk
}

achieve good quality performance. But on the basis of inappropriate training load, this can lead to negative body response taking the age into consideration. Alpine skiing is a sport with a very complex structure and a high variability of movements. To master them a complex development of physical abilities is needed and just these abilities are a limiting factor of performance in Alpine skiing (Bedřich, Bedřich, \& Klouček, 2008). A high level of development of coordination skills of alpine skiers has a positive effect on achievement of optimal technique, to further improve as well as increase adaptation to changing conditions and achieving maximum performance (Žídek, Blahutová, \& Petrovič, 1994). According to Ljach (1989) the development of coordination skills contributes to faster motor learning which leads to more perfected technique in a given sport. Fine motor skills predetermined 
by coordination skills are the basis of mastering and improving of the most effective techniques and therefore a decisive factor. The development of coordination skills is already manifested in childhood unlike conditioning. According to Starosta (2003) it is also necessary to move the centre of sport training from conditioning to coordination skills which development is mostly not connected to the risk of overtraining the athlete. Therefore it is understandable that considerable attention be paid to the development of these skills in early stages of the sport preparation. According to Zálešák and Hellebrandt (1989) balance skills, used to keep or correct equilibrium position in fast and relatively large changes in body position, are determined for alpine skiing. Efficiency of most ski-motion activities depends just on the ability to maintain balance. This point was also confirmed by LeMaster (2010). Balance enables movement in an unsteady position and according to Źídek (1992) its level of the development also influences a basic stance, maintaining balance when skiing through rough terrain, getting a feel for ski edges and the ski's contact points, turning the ski, shifting weight from one ski to the other and turning at the same time, vertical movement and thus allows a skier to maintain the flow and rhythm of riding. A high level of the development of balance allows a skier to maintain stability of the body as it lays into curves even at higher speed. Forward and backward balance allows the skier faster transition from the phase of curve exit into the steering phase, then the skier must return to the start position and to move the body centre of gravity to the front and get it as low as possible. Maršík (2003) states that balance with connection to the flexibility and movement of lower limbs enables the outset of a turn and ski edgeposition to a skier.

The selection of exercises for the development of dynamic balance should be wide; the exercises must change often and gradually become more difficult. As a general rule they are used at the beginning of training session, immediately after a warm-up and the exercises require optimal motivation, concentration and enough patience (Blahutová \& Kmet', 2010). Volume, intensity and frequency of individual exercises depend on the age and performance level. When the task is harder and children are younger, then the loading time is shorter. It is important to include rest between exercises to give child's body enough time to recover (not to do exercises in a state of fatigue) (Lednický \& Doležajová, 2002). The frequency of exercise stimuli is important (minimum of 3-5 times a week), while its volume does not have to be large; just 15 to 20 minutes is enough in one training unit (Blahutová \& Kmet', 2010). It is necessary to apply lower volume, but greater frequency of specific loads (Korček et al., 1996). The coaches, with current possibilities for using specific devices such as fit balls, balance platforms, balance beams, slackline etc., have the possibility to use nearly an inexhaustible amount of various exercises for the development of balance and other motor skills. For many years, many top skiers have used inline skates in their "dry" training (Č́stka, Kolovská, \& Votík, 2005). It is one of the most effective specific means which are used and serve as an optimal form of training for practicing carving in alpine skiing and they are also used for the development of balance skills. The basic load and the sequence of the movements is similar to the technique of carving and also cutting the curves and the shifting of the skier's weight from the outside edge onto the inside one and opposite are similar (Roschinsky, 2004). Therefore "inline skating" is used for training and improvement of basic skiing skills. Moreover, inline skating is the best imitation with similar loading of legs and involvement of muscles as in skiing because inline skates provide a sense of sliding, stance and edge change and the technique for making curves are very similar (Ladig \& Růger, 2003).

The main purpose of this paper was to assess the influence of 9 week specialized motion program on the changes in the level of development balance abilities of 8-10 year old children in alpine skiing. This specialized motion program consisted of exercises on inline skates and from balance exercises on non-specific equipment. It was included in the preparatory period in the stage of preliminary sport preparation.

By the application of a 9 week movement program we predict that the experimental group will achieve positive changes in the level of the static and dynamic balance.

After undergoing 9 weeks of general training process, we do not predict changes in the level of development of the static and dynamic balance in the control group.

\section{Methods}

The experimental group (EG) consisted of 12 subjects of school age from the ski club Ski team one from Banská Bystrica. The control group (CG) consisted of 12 subjects from the Ski club ŠK Kartík from Banská Bystrica. Age and somatic differences between the groups were not statistically significant (Table 1).

In this study we used a single-factor parallel experiment with two groups, in which in the experimental group during the preparatory period we applied a 9 week specialized training program (STP) through inline skating focused on the development of balance abilities (from $12^{\text {th }}$ September to $13^{\text {th }}$ November 2011). Exercises focused on the development of 
balance abilities should be applied long-term and the first changes are visible after 8-10 weeks of systematic training (Blumme, 1981; Tonkovičová \& Rupčík, 2008). Rozzi et al. (1999) discovered that even after 4 week program focused on the development of balance, there were positive changes in the level of static balance. Also the quality of one leg stand of tested individuals improved. The control group completed a 9 week generally focused training process on the development of the physical abilities from $12^{\text {th }}$ September to $13^{\text {th }}$ November 2011. Both tested groups completed 3 training sessions (in the duration of 90 minutes) within a one week microcycle in the preparatory period in the stage of preliminary sport preparation in alpine skiing (Table 2). The experimental group completed a total of 90 minutes of the specialized training program per week, of which 60 minutes were special exercises on inline skates and 30 minutes were exercises for the development of balance skills on non-specific tools. In addition, they completed 60 minutes per week of exercises on inline skates. The control group completed a total of 75 minutes per week and exercises for the development of balance skills, of which 60 minutes on inline skates and 15 minutes on non-specific tools. Children included in the experimental and control group have mastered the basics of inline skating. This experiment took place in Banská Bystrica and around. The initial and final testing of both experimental and control groups took place in standard conditions in the laboratory of Department of Physical Education and Sports at Faculty of Humanities (currently Faculty of Arts), Matej Bel University.

Table 1

Basic age and somatic characteristics $(M \pm S D)$ of the groups at the beginning and at the end of the research

\begin{tabular}{|c|c|c|c|c|c|}
\hline & \multicolumn{2}{|c|}{ Experimental group } & \multicolumn{2}{|c|}{ Control group } & \multirow[b]{2}{*}{$p$} \\
\hline & Input & Output & Input & Output & \\
\hline Age (years) & $9.41 \pm 0.90$ & $9.58 \pm 0.90$ & $9.19 \pm 0.84$ & $9.36 \pm 0.84$ & $.343^{\mathrm{ns}}$ \\
\hline Body height $(\mathrm{cm})$ & $142.04 \pm 5.49$ & $143.33 \pm 5.37$ & $134.88 \pm 5.27$ & $136.00 \pm 5.41$ & $.007 * *$ \\
\hline Body weight (kg) & $37.78 \pm 7.65$ & $37.78 \pm 7.37$ & $30.99 \pm 4.61$ & $31.58 \pm 4.73$ & $.011^{*}$ \\
\hline BMI $\left(\mathrm{kg} \cdot \mathrm{m}^{-2}\right)$ & $18.60 \pm 2.97$ & $18.28 \pm 2.93$ & $16.92 \pm 1.77$ & $16.93 \pm 1.61$ & $.174^{\mathrm{ns}}$ \\
\hline
\end{tabular}

* statistically significant at $p<.05,{ }^{* *}$ statistically significant at $p<.01,{ }^{\text {ns }}$ not statistically significant.

Table 2

Training session content in experimental and control group in microcycle

\begin{tabular}{|c|c|c|}
\hline Microcycle & Experimental group & Control group \\
\hline $\begin{array}{l}\text { Training session } 1 \\
\text { (road - straight track) }\end{array}$ & $\begin{array}{l}\text { Light skating - } 1 \mathrm{~km} \text {, warm-up } \\
\text { "Alphabet" (SMP) special exercises on in-line } \\
\quad \text { skates }^{\mathbf{1}} \mathbf{-} \mathbf{3 0} \text { min } \\
\text { Exercises on in-line skates ( } 30 \mathrm{~min}) \text { : slalom, giant } \\
\quad \text { slalom through courses (cones) } \\
\text { Cool down by skating }-1 \mathrm{~km}\end{array}$ & $\begin{array}{l}\text { Light skating - } 1 \mathrm{~km} \text {, warm-up } \\
\text { Exercises on in-line skates ( } 60 \mathrm{~min}) \text { : slalom, giant } \\
\text { slalom through courses (cones) } \\
\text { Cool down by skating - } 1 \mathrm{~km}\end{array}$ \\
\hline $\begin{array}{l}\text { Training session } 2 \\
\text { (gym) }\end{array}$ & $\begin{array}{l}\text { Easy jogging, warm-up } \\
\text { Development of balance abilities using nonspecific } \\
\text { equipment (SMP) })^{\mathbf{2}} \mathbf{3 0} \mathbf{~ m i n} \text {, general develop- } \\
\text { ment of motor abilities ( } 30 \mathrm{~min}) \\
\text { Stretching, cool down jogging }\end{array}$ & $\begin{array}{l}\text { Easy jogging, warm-up } \\
\text { Development of balance abilities - } 30 \text { min (every } \\
\text { second week it is } 15 \text { min per week) - using } \\
\text { devices for the development of balance abilities } \\
\text { (Traditional Balance Bench), general develop- } \\
\text { ment of motor abilities ( } 30 \text { min) } \\
\text { Stretching, cool down jogging }\end{array}$ \\
\hline $\begin{array}{l}\text { Training session } 3 \\
\text { (road - slight hill) }\end{array}$ & $\begin{array}{l}\text { Light skating - } 1 \mathrm{~km} \text {, warm-up } \\
\text { "Alphabet" (SMP) special exercises on in-line } \\
\text { skates }^{\mathbf{1}} \mathbf{-} \mathbf{3 0} \text { min } \\
\text { Exercises on in-line skates ( } 30 \mathrm{~min}) \text { : slalom, giant } \\
\text { slalom through courses (cones) } \\
\text { Cool down by skating }-1 \mathrm{~km}\end{array}$ & $\begin{array}{l}\text { Cycling (long distances to develop endurance) } \\
\text { Hiking (uphill running) }\end{array}$ \\
\hline
\end{tabular}

Note. $\quad{ }^{1}$ set of special exercises for in-line roller skates (Rázusová, 2012); ${ }^{2}$ energetics balance board, small trampoline, balance beam $=$ Traditional Balance Bench, slack-line, monocycle, fitball (Rázusová, 2012). 
To determine the level of balance abilities we used the following motor tests:

\section{Test 1 - Flamingo Balance Test (T1)}

Description: tested subject stands on a narrow beam (50 cm long, $4 \mathrm{~cm}$ high, $2 \mathrm{~cm}$ wide) on his/her preferred foot, places the hands on the hips and tries to balance successfully on a single leg. Hands are placed on the hips all the time and subjects are not allowed to touch the ground with any part of their body. Start the stopwatch when the subject is in the described pose until the subject loses balance and then stop the stopwatch, start timing again in the duration of 1 minute when the subject stands on a beam again.

Evaluation: the total number of attempts needed to keep balance in the duration of 1 minute is counted (Lednický \& Doležajová, 2002).

Followed factor: the level of static balance.

\section{Test 2 - Runs over the bench with 3 turnabouts (T2)} Description: tested subject stands behind the bench, faces the bench $(3.6 \mathrm{~m}$ long and $10 \mathrm{~cm}$ wide). The subject places one leg on the bench. Start at one end, step up onto the bench and walk the length to the other end. During the walk make $3 \times 360$ degree turns. Two falls from the bench are allowed when losing balance. On the other hand the test must be done again; a maximum of 2 attempts may be performed. The time is measured from the starting signal to the touch of the ground behind the beam.

Evaluation: subject is given one trial attempt and 2 measured attempts. For each touch of the ground $1 \mathrm{~s}$ is added to the measured time. The best attempt is recorded with the accuracy of $0.01 \mathrm{~s}$ (Šimonek, 1998). Followed factor: the level of dynamic balance.

\section{Test 3 - Postural sway assessment during one leg stance (T3 A)}

Description: tested subject stands without shoes on the stabilographic platform - stand on the right leg for $30 \mathrm{~s}$ and the free leg is flexed at the knee and the foot of this leg held close to the buttocks - place the hands on the hips (change). Tested subjects were instructed to minimize postural sway by standing upright and motionless. The Fitro Sway Check (Comenius University, Bratislava, Slovakia) stabilometric system monitors the horizontal movement of centre of gravity through the changes of the pressure of contact surfaces of the feet on the pad. The average speed movement of gravity and the length of the trajectory in both antero-posterior and medio-lateral direction are used as a criterion of stable stance (Hamar, 1997).

Evaluation: COG - the projection of the centre of mass on the surface on the basis of which a computer calculates the average of COG amplitude from the given trajectory. From a methodological point of view $\mathrm{COG}$ is a direct indicator of stabilization but at the same time it is also indirect indicator of the latent theoretical concept which is postural stability. This parameter after mathematical conversion correlates with the projection of the COG to supporting base, COG. COG is recorded in time and according to a test which takes place on the platforms, it continues to work with this parameter. Using stabilometric measurement the average values of individual parameters, values for the given period in interval of seconds $\left(\mathrm{m} \cdot \mathrm{s}^{-1}\right)$ was obtained.

Followed factor: the level of static balance.

\section{Test 3 - Dynamic sway assessment during one leg stance (T3 B)}

Description: tested subject stands barefoot on the dynamometric platform: position of the feet is a side-by-side position - hands on the hips and the subject tries to copy a trajectory shown on the monitor in the duration of $30 \mathrm{~s}$ by moving the centre of gravity and lower limbs. The test monitors the horizontal movement of centre of gravity on the basis of the analysis of the distribution of the vertical force. This is registered using the dynamometric platform with 4 tensometric sensors of $100 \mathrm{~Hz}$ frequency connected to the computer with a special program (Hamar, 1997). The Fitro Sway Check device monitors the movement of body's centre of gravity through changes in the pressure of each foot. Evaluation: $\mathrm{COG}$ - the projection of the centre of mass on the surface on the basis of which a computer calculates the average of $\mathrm{COG}$ amplitude from the given trajectory. From methodological point of view COG is a direct indicator of stabilization but at the same time it is also an indirect indicator of the latent theoretical concept which is postural stability. This parameter after mathematical conversion correlates with the projection of the COG to supporting base, COG. The system is capable of detecting COG amplitude with the accuracy of $0.1 \mathrm{~mm}$ (Hedbávný, 2011).

Followed factor: the level of dynamic balance.

We investigated the statistical dependence in the software program, SPSS Statistic (version 17; IBM, Armonk, NY, USA). For comparing the homogeneity of groups we used the values of BMI and decimal age and the values of the input testing of motoric laboratory tests (T3 A, T3 B). Test of normality of data distribution was used; therefore we used a nonparametric Wilcoxon unpaired test for evaluation.

To determine a statistically significant impact of specialized movement program for changes in the level of development of balance abilities in the experimental group and impact of generally focused training 
process in the control group, we used a nonparametric Wilcoxon paired test (T1, T2, T3 A, T3 B) when comparing the performance values of the input and output testing in the monitored groups.

\section{Results}

Compared to input testing (during 9 weeks), we noted the improvement in average of performance in the output testing of the subjects of the experimental group due to the influence of the specialized movement program in both tests detecting the level of the development of static balance (T1, T3 A). In the test T1, the subjects of the experimental group reached improvement in average of performance due to the influence of the specialized training program (about 2.75 attempts) and in the test T3 A on the left foot was by about $11.70 \%$ (about $4.5 \mathrm{~m} \cdot \mathrm{s}^{-1}$ ) and on the right foot it was by about $14.22 \%$ (about $5.49 \mathrm{~m} \cdot \mathrm{s}^{-1}$ ). In the experimental group in the test $\mathrm{T} 1$, we measured the input testing 6.17 attempts as the average of performance, in the output it was
3.42 and in the test T3 A on the left foot the input was $38.74 \mathrm{~m} \cdot \mathrm{s}^{-1}$; the output was $33.13 \mathrm{~m} \cdot \mathrm{s}^{-1}$ (Table 3 ). For individual assessment, in the experimental group, just one subject reached worsening in the test T3 A on the left foot and in the test T1 we noted stagnation. We explain the worsening due to low participation in the trainings (48.15\%).

Compared to the input performances, the control group reached no significant differences after 9 weeks due to the general training process focused on the development of motor skills. We also noted no significant differences in the average of performance in both tests detecting the level of the static balance. In the test T1 it was by about $6.91 \%(-0.42)$, in the test T3 A on the left foot it was by about $8.27 \%\left(-3.45 \mathrm{~m} \cdot \mathrm{s}^{-1}\right)$ and on the right foot it was by about $6.22 \%\left(-2.59 \mathrm{~m} \cdot \mathrm{s}^{-1}\right)$. In the test $\mathrm{T} 1$ during the input testing, measured average of performance of the subjects in the control group was 6.08 , at the output testing it was 6.5 and in the test T3 A on the left foot the input was $41.71 \mathrm{~m} \cdot \mathrm{s}^{-1}$; the output was $45.16 \mathrm{~m} \cdot \mathrm{s}^{-1}$ and on the right foot the input was $41.65 \mathrm{~m} \cdot \mathrm{s}^{-1}$; the output was $44.24 \mathrm{~m} \cdot \mathrm{s}^{-1}$ (Table 4 ).

Table 3

Static balance in experimental group

\begin{tabular}{|c|c|c|c|c|c|c|}
\hline & \multicolumn{2}{|c|}{ T1 (attempts) } & \multicolumn{4}{|c|}{ T3 A $\left(\mathrm{m} \cdot \mathrm{s}^{-1}\right)$} \\
\hline & \multirow[b]{2}{*}{ Input } & \multirow[b]{2}{*}{ Output } & \multicolumn{2}{|c|}{ Left limb } & \multicolumn{2}{|c|}{ Right limb } \\
\hline & & & Input & Output & Input & Output \\
\hline$M$ & 6.17 & 3.42 & 38.74 & 34.21 & 38.62 & 33.13 \\
\hline Minimum & 2 & 0 & 27.2 & 29.0 & 31.5 & 25.5 \\
\hline Maximum & 11 & 7 & 55.7 & 44.3 & 50.4 & 39.4 \\
\hline$S D$ & 2.55 & 2.35 & 7.42 & 5.33 & 5.70 & 4.00 \\
\hline$M d n$ & 6.5 & 4.0 & 37.20 & 32.50 & 36.65 & 33.70 \\
\hline$p$ & \multicolumn{2}{|c|}{$.002 * *$} & \multicolumn{2}{|c|}{$.004^{* *}$} & \multicolumn{2}{|c|}{$<.001 * * *$} \\
\hline
\end{tabular}

$* *$ statistically significant at $p<.01, * * *$ statistically significant at $p<.001$.

Table 4

Static balance in control group

\begin{tabular}{|c|c|c|c|c|c|c|}
\hline & \multicolumn{2}{|c|}{ T1 (attempts) } & \multicolumn{4}{|c|}{ T3 A $\left(\mathrm{m} \cdot \mathrm{s}^{-1}\right)$} \\
\hline & \multirow[b]{2}{*}{ Input } & \multirow[b]{2}{*}{ Output } & \multicolumn{2}{|c|}{ Left limb } & \multicolumn{2}{|c|}{ Right limb } \\
\hline & & & Input & Output & Input & Output \\
\hline$M$ & 6.08 & 6.5 & 41.71 & 45.16 & 41.65 & 44.24 \\
\hline Minimum & 1 & 1 & 25.7 & 30.9 & 30.5 & 30.3 \\
\hline Maximum & 10 & 11 & 69.2 & 69.0 & 57.8 & 82.0 \\
\hline$S D$ & 2.68 & 3.09 & 11.60 & 12.52 & 12.04 & 14.74 \\
\hline$M d n$ & 6.5 & 6.5 & 39.40 & 41.85 & 38.90 & 40.50 \\
\hline$p$ & \multicolumn{2}{|c|}{$.820^{\mathrm{ns}}$} & \multicolumn{2}{|c|}{$.924^{\mathrm{ns}}$} & \multicolumn{2}{|c|}{$.945^{\mathrm{ns}}$} \\
\hline
\end{tabular}

${ }^{\text {ns }}$ not statistically significant. 
When comparing measured values in the initial and final testing of the experimental group, we observed statistically significant improvement of the level of development in static balance on the level of significance $p<.001$ in both tests for determining the level of static balance. Differences in both tests in the control group were not statistically significant when comparing the performance in the initial and final testing (Table 3, 4).

In the dynamic balance test $\mathrm{T} 2$ the experimental group improved their performance about 15.64\% $(2.03 \mathrm{~s})$ due to the influence of the 9 week specialized training program, whereas measured average values in the initial testing were $12.89 \mathrm{~s}$ and in the final testing $10.95 \mathrm{~s}$. They improved in the test T3 B about $12.92 \%$ $(4.24 \mathrm{~mm})$, average values in the initial testing were $32.83 \mathrm{~mm}$ and in the final testing $28.59 \mathrm{~mm}$ (Table 5). All subjects of the experimental group achieved improvement except the subject who worsened in the test of dynamic balance as well as in the test of static balance, which was explained by significantly low participation (only 40\%). The control group achieved no worse significant differences in the average performance in the test $\mathrm{T} 2$ about $0.51 \%(-0.08 \mathrm{~s})$ under the influence of generally focused training process for the development of motor abilities in time interval of 9 weeks, where the average performance of the initial testing was $15.71 \mathrm{~s}$ and the average performance of the final testing was $15.79 \mathrm{~s}$. In the test T3 B the performance showed no significant differences to be worse, about $2.32 \%(-0.69 \mathrm{~mm})$, the average performance of the initial testing was $29.8 \mathrm{~mm}$, the average performance of the final testing was $30.49 \mathrm{~mm}$ (Table 6).

When comparing measured values of the performance in the initial and final testing of the experimental group in tests T2 and T3 B, we observed statistically significant improvement of the level of development dynamic balance on the level of significance $p<.01$ (Table 5). Differences in both motor tests, used for

Table 5

Dynamic balance in experimental group

\begin{tabular}{lrrrrr}
\hline & \multicolumn{2}{c}{ T2 $(\mathrm{s})$} & & \multicolumn{2}{c}{ T3 B $(\mathrm{mm})$} \\
\cline { 2 - 3 } \cline { 5 - 6 } & Input & Output & & Input & Output \\
\hline$M$ & 12.98 & 10.95 & & 32.83 & 28.59 \\
Minimum & 10.48 & 8.25 & & 28.9 & 24.9 \\
Maximum & 16.25 & 14.37 & & 48.0 & 33.4 \\
$S D$ & 1.80 & 2.05 & & 5.54 & 3.54 \\
$M d n$ & 13.36 & 10.80 & & 30.55 & 27.90 \\
$p$ & \multicolumn{2}{c}{$.002^{* *}$} & & \multicolumn{2}{c}{$.005^{* *}$} \\
\hline
\end{tabular}

$* *$ statistically significant at $p<.01$. determining the level of dynamic balance in the control group during comparing the initial and final tests, were not statistically significant (Table 6).

\section{Discussion}

The stage of preliminary sport preparation in alpine skiing has its own characteristics of the structure of training process and training load. First of all, age-specifics of children need to be taken into account. Priority for every coach must be optimal physical development and health concerning each entrusted athlete. At this stage of sport training, we deal with the development of motor abilities, mastering motor skills and shaping the overall personality of the athlete. We try to achieve optimal technique and performance on the basis of adequate load.

Depending on the structure of the sport performance and sensitive period, in which the subjects of the experimental group were, we currently focused on the development of balance abilities because according to most of the authors the efficiency of most ski-motion activities depends upon balance (LeMaster, 2010; Maršík, 2003; Zálešák \& Hellebrandt, 1989). A high level of the development of balance abilities has positive influence on sport performance in alpine skiing.

In the experimental group, when preparing the specialized training program, we also focused on application of specific ski-motions into nonspecific movements using methods for the development of balance abilities of children of school age. We had to take into consideration the complexity and adequacy of all exercises, its training load with respect to age and performance of skiers.

As we found out, selected exercises on nonspecific means may significantly contribute to the development of balance abilities, but they also have a motivational

Table 6

Dynamic balance in control group

\begin{tabular}{lcccccc}
\hline & \multicolumn{2}{c}{ T2 $(\mathrm{s})$} & & \multicolumn{2}{c}{ T3 B $(\mathrm{mm})$} \\
\cline { 2 - 3 } \cline { 5 - 6 }$M$ & Input & Output & & Input & Output \\
\hline Minimum & 15.71 & 15.79 & & 29.8 & 30.49 \\
Maximum & 12.98 & 12.66 & & 25.9 & 23.4 \\
$S D$ & 1.13 & 18.24 & & 37.7 & 47.2 \\
$M d n$ & 15.88 & 16.48 & & 29.1 & 28.25 \\
$p$ & \multicolumn{3}{c}{$.633^{\mathrm{ns}}$} & & \multicolumn{3}{c}{$.575^{\mathrm{ns}}$} \\
\hline
\end{tabular}

${ }^{\mathrm{ns}}$ not statistically significant. 
character and positively contribute to prevention of injuries of the musculoskeletal system as well.

Results of this study confirmed that younger school age is a sensitive period for the development of balance abilities (Belej, 2001; Chovanová \& Majherová, 2006; Hirtz, 1982; Kohoutek \& Hirtz, 2004; Lednický \& Doležajová 2002; Šimonek et al., 2008) however our study has some limitations such as low number of subjects and lack of random division into groups.

\section{Conclusions}

The experimental group improved due to the specialized training program in all tests for balance abilities in the range of $13.49-38.52 \%$, improvement of all tested subjects by an average of $19.81 \%$. We can confirm that all tested subjects statistically significantly improved in all tests (T1, T2, T3 A, T3 B) for balance abilities due to the specialized training program.

As it was confirmed, a 9 week motion program within 3 training session per week, including the exercises on inline skates and exercises for the development of balance abilities on non-specific equipment in the duration of 30 minutes at the beginning of each training session, was long enough to have a positive influence on the development of balance abilities of children of school age in Alpine skiing.

\section{Acknowledgments}

This contribution was supported by grants Optimization of training load in individual sports (No. VEGA $1 / 0322 / 10)$ and Adaptive effect of training load in individual sports (No. VEGA 1/1158/12).

\section{References}

Bedřich, L., Bedřich, P., \& Klouček, J. (2008). Sjezdové lyžování nejen $\mathrm{z}$ aspektu tělesné zátěže [Downhill skiing not only from the aspect of physical train]. SKI MAGAZÍN, 13, 18-20.

Belej, M. (2001). Motorické učenie [Motor learning]. Prešov: Slovenská vedecká spoločnost’ pre telesnú výchovu a šport a Prešovská univerzita v Prešove.

Blahutová, A., \& Kmet,, T. (2010). Rozvoj koordinačných schopností v športovej príprave detí vo veku od 5-12 rokov v zjazdovom lyžovaní [Development of coordination abilities in sports training of children at the age of 5-12 years in downhill skiing]. Telesná výchova a šport, 20(3), 5-39.

Blume, D. (1981). Charakteristik der koordinations Fahigkeiten und Möglichkeiten Iber Entwicklung im Trainings prozes [Characteristics of coordination abilities and possibilities of its development in a training process]. Zeitschrift, 3, $17-41$.

Částka, K., Kolovská, I., \& Votík, J. (2005). Jak dokonale zvládnout carving [How to execute a good carving technique in skiing]. Praha: Grada.

Chovanová, E., \& Majherová, M. (2006). Sledovanie reakčnej schopnosti v mladšom školskom veku [Monitoring of reactivity at a younger schol age]. Pohyb, šport, zdravie, 3(1), 70-75.

Hamar, D. (1997). Stabilografický systém FITRO Sway Check [Stabilographic system FITRO SwayCheck]. Bratislava: Univerzita Komenského.

Hedbávný, P. (2011). Vliv úrovně rovnováhových schopností na provedení vybraných gymnastických pohybových struktur [Influence of balances abilities on performance of gymnastics movement structures] (Doctoral dissertation). Masarykova univerzita, Fakulta sportovních studií, Brno.

Hirtz, P. (1982). Koordinačné schopnosti - charakteristika, dynamika, dynamika vývinu a možnosti ovplyvnenia [Coordination abilities - characterization, dynamics, dynamics of development and opportunities of influencing]. Tréner, 6, 280-284.

Kohoutek, M., \& Hirtz, P. (2004). Výběr sportovních talentů v lyžování - etapa předsportovní [Selection of sports talents in skiing - preliminary sport preparation]. In T. Perič \& J. Suchý (Eds.), Identifikace pohybových talentů (pp. 25-29). Praha: Univerzita Karlova.

Korček, F., Hatiar, B., Havlíček, I., Šimonek, J., Kampmiller, T., \& Laczo, E. (1996). Teória a didaktika športu [Theory and didactics of sport]. Bratislava: Univerzita Komenského.

Ladig, G., \& Rüger, F. (2003). Inline korčulovanie [Inline skating]. České Budějovice: Koop.

Lednický, A., \& Doležajová. L. (2002). Rozvoj koordinačných schopností [Developing coordination abilities]. Bratislava: Slovenská vedecká spoločnost̉ pre telesnú výchovu a šport.

LeMaster, R. (2010). Ultimate skiing. Champaign, IL: Human Kinetics.

Ljach, V. I. (1989). Koordinačné schopnosti žiakov [Coordination abilities of pupils]. Minsk: Polymnja.

Maršík, J. (2003). Carving. Praha: Grada.

Rázusová, Z. (2012). Vplyv špecializovaného pohybového programu na zmeny úrovne rozvoja rovnováhových schopností u detí mladšieho školského veku v zjazdovom lyžovaní [The influence of a specialized movement program on the changes in the level of development balance abilities in children of younger schol age in downhill skiing] (Doctoral dissertation). Univerzita Mateja v Banskej Bystrici, Faculty of Humanities, Banská Bystrica.

Roschinsky, J. (2004). Carving - fascination on skis. Oxford: Meyer and Meyer Sport.

Rozzi, S. L., Lephart, S. M., Sterner, R., \& Kuligowski, L. (1999). Balance training for persons with functionally unstable ankles. Journal of Orthopaedic and Sports Physical Therapy, 29, 478-486.

Starosta, W. (2003). Motoryczne zdolności koordynacyjne. Znaczenie, struktura, uwarunkowania, kstaltowanie [Coordination motor abilities. The meaning, structure, conditions, development]. Warszawa: IASK.

Šimonek, J. (1998). Hodnotenie a rozvoj koordinačných schopností 10-17ročných chlapcov a dievčat [The assessment and 
development of coordination abilities of 10-17 years old boys and girls]. Nitra: Univerzita Konštantína Filozofa v Nitre.

Šimonek, J., Koštial, J., Doležajová, L., Lednický, A., Halmová, N., Kalinková, M., ... Mal'covský, J. (2008). Normy koordinačných schopností pre 11-15 ročných športovcov [The norms of coordination abilities for 11-15 years old sportsmen]. Nitra: Univerzita Konštantína Filozofa v Nitre.

Tonkovičová, A., \& Rupčík, L. (2008). Športová gymnastika ako prostriedok rozvoja koordinačných schopností [Gymnastics as a means of developing coordination skills]. In J. Brod'áni \& P. Horička (Eds.), Šport a zdravie
2008 (pp. 48-51). Nitra: Univerzita Konštantína Filozofa v Nitre.

Zálešák, M., \& Hellebrandt, V. (1989). Lyžovanie, zjazdové disciplíny [Skiing, downhil disciplines]. In J. Šimonek (Ed.), Modelovanie dlhodobej športovej prípravy $\mathrm{v}$ individuálnych športoch (pp. 61-76). Bratislava: Šport.

Žídek, J. (1992). Vzṫah základného a pretekového lyžovania [Connection of basic and competitive skiing]. Telesná výchova a šport, 2(1), 40-42.

Žídek, J., Blahutová, A., \& Petrovič, P. (1994). Lyžovanie [Skiing]. Bratislava: Univerzita Komenského. 